\title{
ANALISIS HASIL PEMERIKSAAN KADAR LOW-DENSITY LIPOPROTEIN (LDL-CHOL) METODE DIREK DAN INDIREK
}

\author{
Syahida Djasang \\ Jurusan Analis Kesehatan Poltekkes Kemenkes Makassar
}

Koresponden : syahida.djasang@gmail.com

\begin{abstract}
ABSTRAK
Low-density lipoprotein $(L D L)$ atau kolesterol jahat apabila banyak terdapat dalam darah menyebabkan akumulasi endapan lemak (plak) dalam arteri (proses aterosklerosis), sehingga aliran darah menyempit. Pemeriksaan LDL kolesterol dapat dilakukan dengan 2 metode yaitu metode direk dan indirek. Pengukuran kadar LDL kolesterol metode direk dilakukan secara langsung pada alat sedangkan metode indirek dilakukan pemeriksaan kadar kolesterol, trigliseridadan HDL kolesterol terlebih dahulu kemudian dihitung dengan rumus friedewald. Tujuan penelitian ini untuk mengetahui perbedaan pemeriksaan LDL kolesterol metode direk dan indirek. Jenis penelitian yaitu penelitian komparative yang dilaksanakan di laboratorium RS. Pelamonia Tk. II Makassar pada bulan Juni 2017 terhadap 10 sampel pasien rawat jalan RS. Pelamonia Tk. II Makassar. Berdasarkan hasil penelitian peneitian diperoleh hasil analisis statistik uji t dengan tingkat kemaknaan $95 \%(\alpha=0,05)$ diperoleh hasil LDL $\mathrm{t}$ hit $(0,1915)<\mathrm{t}$ tab $(1,734)$ artinya tidak ada perbedaan bermakna hasil pemeriksaan LDL kolesterol metode direk dan metode indirek, disarankan pemeriksaan kadar kolesterol sebaiknya menggunakan metode direk karena dapat langsung mengukur kadar LDL kolesterol.
\end{abstract}

Kata Kunci : LDL Kolesterol, direk, indirek

\section{PENDAHULUAN}

Pemeriksaan profil lipid adalah rangkaian tes darah untuk mengukur kadar lemak dalam darah. Hasil tes akan menentukan apakah pasien berpotensi atau telah terserang penyakit, seperti penyakit kardiovaskular, pankreatitis, dan diabetes.

Lipid atau lemak adalah senyawa alami yang membantu fungsi fisiologis normal tubuh. Tubuh menggunakan lemak sebagai sumber tenaga dan membantu proses isolasi. Namun, bila seseorang memiliki kadar lemak darah yang abnormal, maka ia beresiko terserang beragam penyakit dan gangguan kesehatan.

Selain menentukan kadar kolesterol di dalam darah, pemeriksaan profil lipid pun akan mengukur beberapa jenis lemak lainnya. Lemak-lemak ini termasuk low-density lipoprotein atau LDL (dikenal sebagai kolesterol 'jahat'), high-density lipoprotein atau HDL (dikenal sebagai kolesterol 'baik'), dan trigliserida yang tersimpan dalam jaringan lemak sebagai sumber tenaga. Hasil tes ini adalah pemeriksaan profil lipid yang dapat menunjukkan kadar kolesterol LDL dan rasio kolesterol HDL. 
Uji kolesterol atau disebut juga panel lipid atau profil lipid, mengukur kadar lemak (lipid) dalam darah. Pemeriksaan ini memerlukan persiapan puasa mulai 12 jam sebelumnya (tidak makan atau minum, kecuali air putih). Setelah serangan jantung, pembedahan, infeksi, cedera atau kecelakaan, sebaiknya menunggu sedikitnya 2 bulan agar hasilnya lebih akurat. Dalam melakukan pemeriksaan Kolesterol, HDL, LDL dan Trigliserida digunakan metode enzimatik. Pada pemeriksaan HDL juga dapat menggunakan perhitungan friedewald.

Pada perhitungan Friedewald dibutuhkan hasil pemeriksaan kolesterol, trigliserida dan HDL-Chol untuk mendapatkan hasil LDL-Chol. Maka pada perhitungan friedewald melalui 3 tahapan pemeriksaan. Tidak sama halnya dengan pemeriksaan LDL-chol secara direk.

Dalam proses pengendalian mutu dilaboratorium dikenal ada tiga tahapan penting, yaitu tahap pra analitik, analitik dan pasca analitik. Kesalahan pada proses pra-analitik dapat memberikan konstribusi sekitar $61 \%$ dari total kesalahan laboratorium,sementara kesalahan analitik 25\%, dan kesalahan pasca analitik 14\%. Proses pra analitik dibagi menjadi dua kelompok, yaitu pra-analitik ekstra laboratorium dan pra-analitik intra laboratorium. Proses-proses tersebut meliputi persiapan pasien, pengambilan spesimen, pengiriman spesimen ke laboratorium, penanganan spesimen, dan penyimpanan spesimen.

Pada proses pemeriksaan yang melalui banyak tahapan, dapat pula memberikan kemungkinan keselahan yang terjadi lebih besar dibandingkan proses pemeriksaan yang lebih sedikit tahapan yang dilalui.

Berdasarkan uraian diatas, penulis telah melakukan penelitian tentang perbandingan hasil pemeriksaan LDL-Chol (Low-density lipoprotein) metode Direk dan Indirek.

\section{METODE}

Jenis Lokasi dan Waktu Penelitian

Jenis penelitian ini dilakukan dengan menggunakan penelitian comparative di laboratorium, untuk menganalisis hasil pemeriksaaan Low-Densitiy Lipoprotein (LDLChol) metode direk dan indirek. Lokasi penelitian ini dilaksanakan di Rumah Sakit PelamoniaTK. II Makassar. Waktu penelitian dilaksanakan pada bulan Juni 2017.

Populasi, Sampel Penelitian, alat dan bahan

Populasi dalam penelitian ini adalah pemeriksaan Kolesterol metode CHOD-PAP Trigliserida metode GPO-PAP, HDL-Chol metode Direk, LDL-Chol metode Direk dan menggunakan perhitungan Friedewald. Sampel penelitian adalah pemeriksaan LDL-Chol sebanyak 10 sampel untuk masing-masing metode yang diambil dengan menggunakan teknik random sampling. Kriteria sampel dalam penelitian ini adalah sampel darah pasien yang berpuasa 12-14 jam (tidak makan dan minun, kecuali minum air putih). Alat yang digunakan diantaranya Mindray BA88A, Spoit, Stuing, Kapas alcohol, Pipet mikro, Rak tabung, Tabung reaksi, Tips kuning, Tissue, Sentrifuge. Bahan yang digunakan diantaranya reagen kolseterol PAP test kit, reagen Trigliserida test kit, 
reagen HDL-Chol test kit, reagen LDL-Chol test kit, serum kontrol, serum pasien.

\section{Pengumpulan data dan Cara Kerja} Sampel pemeriksaan:

Tempat yang akan ditusuk dibersihkan dengan kapas alkohol $70 \%$ dan biarkan sampai kering. Jika memakai vena fossa cubiti; pasanglah ikatan pembendung pada lengan atas dengan tujuan adanya statis vena. Tegangkanlah kulit diatas vena itu dengan jari-jari tangan kiri supaya vena tidak dapat bergerak. Tusuklah vena yang terlihat dengan semprit sampai sampai ujung jarum masuk kedalam lumen vena. Pembendung direnggang kan atau dilepaskan dan perlahan-lahan ditarik pengisap semprit sampai jumlah darah yang dikehendaki didapat. Taruhlah kapas kering diatas jarum dan tariklah semprit tersebut. Mintalah kepada orang yang darahnya diambil supaya tempat tusukan ditekan selama beberapa menit dengan kapas tadi. Darah dialirkan kedalam wadah atau tabung yang tersedia melalui dinding tabung.

Cara Kerja:

Pemeriksaan Kolesterol

Persiapan sampel: Darah diambil dari vena dengan menggunakan spoit sebanyak $3 \mathrm{cc}$. Darah dimasukkan kedalam tabung yang bersih dan keringt tanpa antikoagulan. Kemudian darah pada tabung dibiarkan membeku selama kurang lebih 15 menit kemudian disentrifugasi dengan kecepatan 3000 rpm selama 15 menit untuk memperoleh serum. Serum yang dihasilkan segera dipisahkan dari bekuannya.
Prosedur kerja:

Dipipet sampel $100 \mu \mathrm{l}$ ke dalam kuvet kemudian baca pada alat. Dari menu utama ditekan Worklist. Ditekan Patient pada menu Worklist kemudian ditekan Add New untuk menambahkan jenis pemeriksaan. Mengisi data pasien pada bagian pada bagian patient demographic kemudian diisi pula sampel characteristic.Dan tentukan jenis parameter yang akan diperiksa. Tekan tanda OK untuk validasi pemeriksaan yang diminta. Diletakkan sampel pada sampel rak sesuai dengan nomor pada sampel characteristic. Untuk meletakkan sampel pada saat alat sedang bekerja dapat dilakukan pada saat lampu sampel tray sudah berwarna hijau. Jika ingin meletakkan sampel pada saat lampumasih berwarna merah, dapat dilakukan dengan menekan tombol pause. Kemudian ditekan tombol Run untuk memulai pemeriksaan.

Nilai normal

Laki- laki dan perempuan : 140-200 $\mathrm{mg} / \mathrm{dl}$

\section{Pemeriksaan Trigliserida}

Persiapan sampel: Darah
diambil dari vena dengan menggunakan spoit sebnayak $3 \mathrm{cc}$. Darah dimasukkan kedalam tabung yang bersih dan kering tanpa antikoagulan. Kemudian darah pada tabung dibiarkan membeku selama kurang lebih 15 menit kemudian disentrifugasi dengan kecepatan 3000 rpm selama 15 menit untuk memperoleh serum. Serum yang dihasilkan segera dipisahkan dari bekuannya.

Prosedur kerja

Dipipet sampel $100 \mu \mathrm{l}$ ke dalam kuvet kemudian baca pada alat. Dari menu utama ditekan Worklist 
Ditekan Patient pada menu Worklist kemudian ditekan Add New untuk menambahkan jenis pemeriksaan. Mengisi data pasien pada bagian pada bagian patient demographic kemudian diisi pula sampel characteristic. Dan tentukan jenis parameter yang akan diperiksa. Tekan tanda OK untuk validasi pemeriksaan yang diminta. Diletakkan sampel pada sampel rak sesuai dengan nomor pada sampel characteristic. Untuk meletakkan sampel pada saat alat sedang bekerja dapat dilakukan pada saat lampu sampel tray sudah berwarna hijau. Jika ingin meletakkan sampel pada saat lampumasih berwarna merah, dapat dilakukan dengan menekan tombol pause. Kemudian ditekan tombol Run untuk memulai pemeriksaan.

Nilai normal : Laki- laki dan perempuan : $36-165 \mathrm{mg} / \mathrm{dl}$

\section{Pemeriksaan HDL-Chol}

Persiapan sampel

Darah diambil dari vena dengan menggunakan spoit sebnayak 3 cc. Darah dimasukkan kedalam tabung yang bersih dan kering tanpa antikoagulan. Kemudian darah pada tabung dibiarkan membeku selama kurang lebih 15 menit kemudian disentrifugasi dengan kecepatan 3000 rpm selama 15 menit untuk memperoleh serum. Serum yang dihasilkan segera dipisahkan dari bekuannya.

Prosedur kerja

Dipipet sampel $100 \mu \mathrm{l}$ ke dalam kuvet kemudian baca pada alat. Dari menu utama ditekan Worklist. Ditekan Patient pada menu Worklist kemudian ditekan Add New untuk menambahkan jenis pemeriksaan. Mengisi data pasien pada bagian pada bagian patient demographic kemudian diisi pula sampel characteristic. Dan tentukan jenis parameter yang akan diperiksa. Tekan tanda OK untuk validasi pemeriksaan yang diminta. Diletakkan sampel pada sampel rak sesuai dengan nomor pada sampel characteristic. Untuk meletakkan sampel pada saat alat sedang bekerja dapat dilakukan pada saat lampu sampel tray sudah berwarna hijau. Jika ingin meletakkan sampel pada saat lampumasih berwarna merah, dapat dilakukan dengan menekan tombol pause. Kemudian ditekan tombol Run untuk memulai pemeriksaan.

Nilai normal : Laki- laki dan perempuan : 30 - $75 \mathrm{mg} / \mathrm{dl}$

\section{Pemeriksaan LDL-Chol}

Persiapan sampel: Darah
diambil dari vena dengan menggunakan spoit sebanyak $3 \mathrm{cc}$. Darah dimasukkan kedalam tabung yang bersih dan kering tanpa antikoagulan. Kemudian darah pada tabung dibiarkan membeku selama kurang lebih 15 menit kemudian disentrifugasi dengan kecepatan 3000 rpm selama 15 menit untuk memperoleh serum.Serum yang dihasilkan segera dipisahkan dari bekuannya.

Prosedur kerja:

Dipipet sampel $100 \mu \mathrm{l}$ ke dalam kuvet kemudian baca pada alat. Dari menu utama ditekan Worklist. Ditekan Patient pada menu Worklist kemudian ditekan Add New untuk menambahkan jenis pemeriksaan. Mengisi data pasien pada bagian pada bagian patient demographic kemudian diisi pula sampel characteristic. Dan tentukan jenis parameter yang akan diperiksa. Tekan tanda OK untuk validasi pemeriksaan yang diminta. Diletakkan sampel 
pada sampel rak sesuai dengan nomor pada sampel characteristic. Untuk meletakkan sampel pada saat alat sedang bekerja dapat dilakukan pada saat lampu sampel tray sudah berwarna hijau. Jika ingin meletakkan sampel pada saat lampumasih berwarna merah, dapat dilakukan dengan menekan tombol pause. Kemudian ditekan tombol Run untuk memulai pemeriksaan.

Nilai normal : Laki- laki dan perempuan : 66- $178 \mathrm{mg} / \mathrm{dl}$

\section{Analisa Data}

Setiap uji coba dianalisa secara teliti, tepat dan benar secara ringkas namun menyeluruh agar diperoleh kesimpulan yang layak dalam bentuk uji t dua pihak .

\section{HASIL}

Berdasarkan hasil penelitian yang dilakukan di RS. Pelamonia Tk. II Makassar pada bulan juni 2017 terhadap 10 pasien rawat jalan yang memeriksakan fraksi lipid diperoleh hasil seperti tabel dibawah ini :

Deskripsi hasil penelitian

Jenis penelitian ini dilakukan dengan menggunakan penelitian komparative di laboratorium. Pengumpulan data dimulai dengan mengambil sampel darah vena pasien rawat jalan di RS. Pelamonia Tk. II Makassar dan dilakukan pemeriksaan LDL kolesterol secara direk dan indirek dilaboratorium. Selanjutnya data yang diperoleh dari metode direk dan indirek dianalisis dengan menggunakan uji statistik t-tes kemuadian ditarik beberapa kesimpulan

Tabel 1.

Hasil pemeriksaan fraksi lipid pada pasien rawat jalan di RS. Pelamonia Tk. II

\begin{tabular}{|c|c|c|c|c|c|}
\hline \multirow[t]{2}{*}{ No } & \multirow[t]{2}{*}{ Kode sampel } & \multicolumn{4}{|c|}{ Hasil pemeriksaan fraksi lipid } \\
\hline & & $\begin{array}{l}\text { Total } \\
\text { Chol }\end{array}$ & Tg & $\begin{array}{l}\text { HDL } \\
\text { Chol }\end{array}$ & $\begin{array}{l}\text { LDL } \\
\text { Chol }\end{array}$ \\
\hline 1 & 001 & 183 & 115 & 66 & 88 \\
\hline 2 & 002 & 258 & 94 & 40 & 172 \\
\hline 3 & 003 & 231 & 127 & 44 & 158 \\
\hline 4 & 004 & 241 & 87 & 57 & 161 \\
\hline 5 & 005 & 182 & 119 & 41 & 114 \\
\hline 6 & 006 & 198 & 88 & 57 & 114 \\
\hline 7 & 007 & 182 & 113 & 21 & 138 \\
\hline 8 & 008 & 179 & 146 & 33 & 117 \\
\hline 9 & 009 & 162 & 97 & 36 & 107 \\
\hline 10 & 010 & 152 & 54 & 80 & 70 \\
\hline
\end{tabular}

Sumber : data primer 2017

Tabel diatas menunjukkan hasil pemeriksaan fraksi lipid yang diperoleh pada pasien rawat jalan di RS. Pelamonia Tk. II Maksassar, dengan memilih nilai kadar

trigliserida $<400 \mathrm{mg} / \mathrm{dl}$ kemudian dimasukkan pada perhitungan friedewald untuk mendapatkan nilai LDL-Chol indire 
Tabel 2.

Hasil pemeriksaan LDL kolesterol direk pada pasien rawat jalan di RS. Pelamonia Tk. II Maksassar

\begin{tabular}{ccc}
\hline No & $\begin{array}{c}\text { Kode } \\
\text { sampel }\end{array}$ & $\begin{array}{c}\text { Hasil pemeriksaan LDL- } \\
\text { Chol metode direk }\end{array}$ \\
\hline 1 & 001 & 88 \\
2 & 002 & 172 \\
3 & 003 & 158 \\
4 & 004 & 161 \\
5 & 005 & 114 \\
6 & 006 & 114 \\
7 & 007 & 138 \\
8 & 008 & 117 \\
9 & 009 & 107 \\
10 & 010 & 70 \\
\hline & $\Sigma \mathrm{x}$ & 123,9 \\
\hline & $\ddot{\mathrm{x}}$ & 12,39 \\
\hline
\end{tabular}

Pada tabel 2. menunjukkan hasil pemeriksaan LDL-Chol metode direk yang diperoleh dengan nilai terendah
$70 \mathrm{mg} / \mathrm{dl}$ dan yang tertinggi 172 $\mathrm{mg} / \mathrm{dl}$ dengan nilai rata-rata 12,39 $\mathrm{mg} / \mathrm{dl}$.

Tabel 3.

Hasil pemeriksaan LDL kolesterol indirek pada pasien rawat jalan di RS.Pelamonia Tk. II

\begin{tabular}{ccc}
\hline No & $\begin{array}{c}\text { Kode } \\
\text { sampel }\end{array}$ & $\begin{array}{c}\text { Hasil pemeriksaan LDL- } \\
\text { Chol metode indirek }\end{array}$ \\
\hline 1 & 001 & 94 \\
2 & 002 & 199 \\
3 & 003 & 164 \\
4 & 004 & 165 \\
5 & 005 & 117 \\
6 & 006 & 123 \\
7 & 007 & 138 \\
8 & 008 & 117 \\
9 & 009 & 107 \\
10 & 010 & 61 \\
\hline & $\mathrm{X}$ & 128,5 \\
\hline & $\ddot{\mathrm{X}}$ & 12,85 \\
\hline
\end{tabular}

Pada tabel 3 menunjukkan hasil pemeriksaan LDL-Chol metode indirek yang diperoleh dengan nilai terendah $61 \mathrm{mg} / \mathrm{dl}$ dan yang tertinggi $199 \mathrm{mg} / \mathrm{dl}$ dengan nilai rata-rata 12,85 $\mathrm{mg} / \mathrm{dl}$. 
Analisis perbandingan LDL metode direk dan indire. Setelah diperoleh data hasil penelitian dari metode direk dan indirek, kemudian data diolah dengan menggunakan uji statistik t-tes yang dapat dilihat seperti tabel dibawah ini :

Tabel 4.

Hasil uji statistika Independent T.tes terhadap pemeriksaan LDL kolesterol indirek pada pasien rawat jalan di RS. Pelamonia Tk. II Makassar.

\begin{tabular}{ccccccc}
\hline \multicolumn{2}{c}{ Pemeriksaan } & $\mathbf{N}$ & $\ddot{\mathbf{x}}$ & SD & t hit & t tab \\
\hline \multirow{2}{*}{ LDL } & Direk & 10 & 12,39 & 32,956 & 0,1915 & 1,734 \\
\cline { 2 - 6 } & Indirek & 10 & 12,85 & 39,660 & & \\
\hline
\end{tabular}

Tabel 4 menunjukkan hasil $\mathbf{t}$ hit $(0,1915)<\mathbf{t} \operatorname{tab}(1,734)$ dengan tingkat kemaknaan $95 \%(\alpha=0,05)$ artinya tidak ada perbedaan yang bermakna hasil pemeriksaan LDL kolesterol metode direk dan metode indirek.

\section{PEMBAHASAN}

Low-density lipoprotein $(L D L)$ atau kolsterol jahat apabila terlalu banyak dalam darah dapat menyebabkan akumulasi endapan lemak (plak) dalam arteri (proses aterosklerosis), sehingga aliran darah menyempit. Plak ini kadang-kadang bisa pecah dan menimbulkan masalah besar untuk jantung dan pembuluh darah. Untuk mengetahui kadar LDL kolesterol dalam darah, dilakukan dengan pemeriksaan laboratorium. Pemeriksaan LDL kolesterol dapat dilakukan dengan menggunakan metode direk dan indirek.

$\begin{array}{ccr}\text { Dari } & \text { hasil } & \text { penelitian } \\ \text { didapatkan } & \text { rata-rata } & \text { hasil }\end{array}$ pemeriksaan LDL-Kolesterol metode Direk $12,39 \mathrm{mg} / \mathrm{dl}$ dan metode Indirek 12,85 mg/dl. Berdasarkan data yang diperoleh dan dilakukan uji statistika didapatkan hasil seperti pada tabel 4.4 menunjukkan bahwa nilai $\mathbf{t}$ hit $(0,1915)<\mathbf{t}$ tab $(1,734)$, dengan tingkat kemaknaan $95 \%(\alpha=$
0,05 ) maka $\mathrm{H}_{\mathrm{O}}$ diterima dan $\mathrm{Ha}$ ditolak, artinya tidak ada perbedaan bermakna hasil pemeriksaan LDL Kolesterol metode direk dan indirek. Karena menggunakan kadar sampel trigliserida yang normal yaitu < $400 \mathrm{mg} / \mathrm{dl}$.

Dari hasil ini menunjukkan bahwa metode direk dan indirek dapat digunakan untuk menegakkan pemeriksaan laboratorium khususnya pemeriksaan LDL Kolesterol. Walaupun demikian pada tabel 4.2 dan tabel 4.3 menunjukkan nilai ratarata kadar LDL Kolesterol metode indirek lebih rendah dibandingkan dengan kadar LDL kolesterol metode direk, Hal ini mungkin karena hasil pengukuran LDL indirek dipengaruhi oleh adanya parameter lain yaitu kolesterol total, trigliserida dan HDL kolesterol.

Ketepatan hasil metode indirek sangat tergantung pada pemeriksaan ketiga parameter tersebut, perkiraan perhitungan yang digunakan pada metode indirek dapat menambah kesalahan dalam penetapan kadar LDL kolesterol. Faktor kesalahan yang dapat terjadi pada metode indirek lebih besar karena selain dari pengaruh hasil pemeriksaan dari ketiga parameter, 
dapat juga diakibatkan dari faktor SDM, reagen, alat dan pada sampling. Pengukuran kadar LDL kolesterol metode direk yaitu dengan melakukan pengukuran langsung pada alat sedangkan pada metode indirek dilakukan pengukuran melalui beberapa tahapan, yaitu dengan melakukan pemeriksaan kadar kolesterol, trigliserida dan HDL kolesterol terlebih dahulu. Kemudian dilakukan perhitungan friedewald untuk mendapatkan hasil pemeriksaan LDL kolesterol. Oleh karena itu pengukuran kadar LDL kolesterol metode indirek dipengaruhi oleh kadar pemeriksaan lain yang dapat mempengaruhi hasil pemeriksaan LDL kolesterol.

\section{KESIMPULAN}

Berdasarkan hasil penelitian yang dilakukan di RS. Pelamonia Tk. II Makassar pada tanggal 7 s/d 8 Juni diperoleh hasil sebagai berikut :

1. Gambaran hasil pemeriksaan LDL-Chol (Low-density lipoprotein) metode direk didapatkan kadar terendah yaitu $70 \mathrm{mg} / \mathrm{dl}$ dan tertinggi yaitu 172 $\mathrm{mg} / \mathrm{dl}$.

2. Gambaran hasil pemeriksaan LDL-Chol (Low-density lipoprotein) metode indirek didapatkan kadar terendah yaitu $61 \mathrm{mg} / \mathrm{dl}$ dan tertinggi yaitu 199 $\mathrm{mg} / \mathrm{dl}$.

3. Tidak ada perbedaan bermakna hasil pemeriksaan LDL kolesterol metode direk dan metode indirek pada $\alpha=0,05(\mathbf{t}$ hit $0,1915<\mathbf{t}$ tab 1,734).

\section{SARAN}

1. Pemeriksaan kadar kolesterol sebaiknya menggunakan metode direk karena dapat langsung mengukur kadar LDL kolesterol yang digunakan pada kadar Trigliserida normal.

2. Peneliti lain disarankan meneliti lebih lanjut mengenai pengaruh peningkatan kadar trigliserida terhadap hasil pengukuran LDLChol menggunakan perhitungan friedewald.

\section{DAFTAR PUSTAKA}

Adi N, 2003. Pengaruh Pemberian Buah Sejati Jambu Mete (Anacardium Occodental L) SANGRAI Terhadap Kadar Kolesterol-Total,

Kolesterol-LDL dan Kolesterol HDL Dalam Serum Tikus Hiperkolesterolemik. Tesis Surabaya : Program Pasca Sarjana Universitas Airlangga.

Anies. 2015. Kolesterol Dan Penyakit Jantung Koroner. ARRUZZ MEDIA: Jogjakarta

Helmiati S, 2014. Buku Saku Interaksi Obat Dan Makanan. Gadjah Madah University Press: Yogyakarta

Kit Insert Book, 2015. Mindray Clinical Chemistry Reagent. Shenzhen Mindray Bio Medical Electronics Co., Ltd Maulana M, 2015. Penyakit Jantung. KATAHATI: Jogjakarta

Murray RK, Grammer DK, Mayes PA, Rodwel VW, 1999. Biokimia Harper. Edisi 24. Jakarta : Penerbit Buku Kedokteran, EGC.

Praseno H, 2015. Penuntun Praktikum Pengendalian Mutu LABKES. Kemenkes RI. 
Jurnal Media Analis Kesehatan, Vol. 8, No.2, November 2017 http://journal.poltekkes-mks.ac.id/ojs2/index.php/mediaanalis e-ISSN : 2621-9557

p-ISSN : 2087-1333

Poedjiaji A, 1994. Dasar-Dasar

Biokimia. Jakarta : PT.

Rineka Cipta. 